\title{
The Pardoo mine: closure planning, implementation and five years of performance monitoring data
}

\author{
S Gregory Mine Earth Pty Ltd, Australia \\ S Mackenzie Mine Earth Pty Ltd, Australia \\ B Bow Atlas Iron Pty Ltd, Australia
}

\begin{abstract}
The Pardoo mine, located in the Pilbara region of Western Australia, is owned by Atlas Iron Pty Ltd. Mining commenced in October 2008 and reserves were depleted in 2013. The Project consisted of 11 open pits, six waste rock landforms and mining infrastructure.

This paper describes the risks to closure that were identified for the Project and the investigations and stakeholder engagement that Atlas undertook to mitigate these risks. The closure works that were undertaken and the results of five years of performance monitoring data, along with a comparison of rehabilitation performance against agreed closure criteria are also described. This represents the halfway mark of the planned 10-year monitoring period.
\end{abstract}

Detailed closure planning commenced in 2010 and was initiated using a risk assessment workshop to identify all closure risks. The highest risk events for closure of the Project included; a poor revegetation outcome, and failure of engineered structures. To mitigate these risks, and others, Atlas undertook a series of targeted closure investigations to ensure that knowledge gaps were filled, and appropriate control mechanisms were implemented. This work facilitated the development of the detailed mine closure plan (MCP), which was submitted and approved in 2013.

Closure works were implemented according to the MCP between late 2013 and early 2014. Closure performance has now been assessed for five years and closure criteria developed for the Project have already been met in some areas.

The early success of closure works at the Project was attributed to the identification of key risks, investigations which closed key knowledge gaps, stakeholder engagement being conducted early in the closure planning process and high-quality closure works.

Keywords: closure performance monitoring, closure criteria, closure works, rehabilitation

\section{Introduction}

The Pardoo mine (the Project) was an iron ore mine that was operated by Atlas Iron Pty Ltd (Atlas). The Project is located approximately $75 \mathrm{~km}$ east of Port Hedland in the Pilbara region of Western Australia. The Project consisted of six deposits which were mined via 11 open pits with waste rock deposited into six waste rock landforms (WRLs). Mining commenced in December 2008 and the last ore was processed in October 2013. The detailed mine closure plan (MCP) for the Project was submitted and approved in November 2013.

Stage 1 closure works were completed in February 2014 and involved the construction of abandonment bunds, the removal of non-essential infrastructure, and reshaping and revegetation works on the WRLs. Essential infrastructure to support the potential for future mining operations and post-closure monitoring were left intact under a program of care and maintenance.

Atlas set a target of 10 years for lease relinquishment after the completion of closure works. This paper represents the progress that has been made at year five, halfway through the relinquishment time frame. 
Uncontrolled surface water and poor revegetation were identified as key risk for the Project and as such, the emphasis in this paper is on the performance of vegetation and surface water management on the WRLs.

This paper describes:

- The closure planning process undertaken at Pardoo.

- Closure works that were undertaken on the WRLs.

- The closure monitoring framework that has been applied to measure performance of surface water management/erosion and vegetation objectives.

- Performance against surface water/erosion and vegetation closure criteria.

To evaluate performance against closure criteria, all available vegetation monitoring reports were reviewed, site inspections were undertaken and an un-manned aerial vehicle (UAV) survey to collect orthophoto and digital elevation model (DEM) data from WRLs was conducted.

\section{$2 \quad$ Closure planning process}

Closure planning at the Project was initiated with the development of a conceptual mine closure plan in 2008 and detailed closure planning started during 2010. The closure planning process adopted by Atlas commenced with a closure risk assessment from which multiple knowledge gaps were identified. Atlas subsequently undertook a program of investigations and studies to fill these knowledge gaps and an extensive stakeholder engagement program. All information collected during the closure planning process was fed into the development of a detailed MCP (Atlas 2013).

\subsection{Closure risk assessment}

A series of mine closure risk assessment workshops were undertaken for the Project. The objectives of the risk assessment were to identify, rank and prioritise risks, to develop management options for risk events that could compromise closure objectives, and to assist with managing uncertainty. The risk assessment process aligned with the Australian and New Zealand Risk Management Standard (AS/NZ 31000:2009) (International Organization for Standardization 2009). Key risk associated with vegetation and surface water/erosion are presented in Table 1.

Table $1 \quad$ Key vegetation and surface water risks

\begin{tabular}{lll}
\hline Event & Cause & Control strategies \\
\hline $\begin{array}{l}\text { Poor } \\
\text { revegetation } \\
\text { outcomes }\end{array}$ & $\begin{array}{l}\text { Insufficient or hostile soil; } \\
\text { inappropriate or poor quality seed; } \\
\text { erosion; excessive fire; grazing } \\
\text { pressure; weeds; poor climatic } \\
\text { conditions }\end{array}$ & $\begin{array}{l}\text { A comprehensive rehabilitation plan was } \\
\text { developed; Detailed design of landforms and } \\
\text { surface water controls were completed; Post- } \\
\text { closure monitoring and maintenance will be } \\
\text { undertaken }\end{array}$ \\
Erosion & $\begin{array}{l}\text { Poor material selection; } \\
\text { uncontrolled surface water flow; } \\
\text { poor landform design, poor }\end{array}$ & $\begin{array}{l}\text { Detailed design of waste landforms and surface } \\
\text { water controls were developed; QA/QC was } \\
\text { undertaken to implement designs; Post-closure }\end{array}$ \\
& revegetation & monitoring and maintenance will be undertaken \\
\hline
\end{tabular}

\subsection{Knowledge gaps and studies}

Gap analysis and risk assessment were used to identify closure opportunities and set planning priorities. Targeted closure investigations were then undertaken to address gaps and risks. The knowledge gaps identified which could be managed and might restrict success of revegetation and rehabilitation at the 
Project were primarily related to uncertainty around the quality and quantity of the topsoil resource and seed requirements. Surface water management was also considered.

In response, Atlas commissioned several investigations including an assessment of the topsoil stockpiles to determine: plant growth properties; the quantity of soil available; and a strategy for deployment of the topsoil resource (Outback Ecology Services (OES) 2012). A soil deficit was identified at the Project so the properties of the subsoil and waste rock were also assessed as a potential growth medium. The subsoil materials were identified as a suitable rehabilitation resource in the absence of topsoil.

Surface treatments including contour ripping, surface drainage control and rock armouring were considered, and area specific seed lists were developed based on local vegetation communities. A plan for seed procurement, treatment and application rates was formulated (Trajectory 2013). A seed specialist was commissioned to assist with these studies.

The key knowledge gaps related to surface water management and erosion on the landforms included uncertainty around the physical/erosion properties of waste rock on the final WRL surfaces, flooding conditions during specified rainfall events, landform design and WRL surface armouring requirements.

Areas of the WRLs were mapped according to their stability characteristics (from a surface erosion perspective) and zones were given a high, medium or low stability classification depending on factors such as degree of weathering, estimated percentage of low stability waste, percentage of fines and the presence of gully erosion (Mine Earth 2012). This helped identify areas on the final WRLs that required additional rock armouring.

Results from flood modelling investigations helped to determine the flood armouring requirements for each WRL (MWH 2013). Water depths were modelled for both 100 -year average recurrence interval and probable maximum precipitation (PMP) events to determine what depth WRLs should be armoured to. The results from the WRL mapping and flood modelling investigations contributed to the final landform designs that were developed for each WRL.

\subsection{Stakeholder consultation}

A closure consultation plan was developed and implemented, which consisted of a series of detailed meetings with relevant stakeholders. Project stakeholders included Commonwealth and State government agencies, native title and traditional owner groups, pastoral leaseholders, and other local/regional groups.

Stakeholder meetings were scheduled in both Port Hedland and Perth to encourage attendance. Initial meetings provided background information and details of closure knowledge gaps. Subsequent meetings were used to present the outcomes of the closure investigations and encourage stakeholders to contribute to investigation outcomes. Later meetings were used to encourage participation in the development of closure objectives, closure criteria and the post-closure monitoring strategy.

\section{Closure works}

Closure works on the WRL slopes commenced with reprofiling to form concave slopes with an overall batter angle of approximately $17.5^{\circ}$ (Figure 1 ). Rock armour was applied in appropriate areas that were identified during the mapping and flood modelling investigations. On the top surface of the WRLs, $1 \mathrm{~m}$ high perimeter crest bunds were constructed, a $5^{\circ}$ backslope was applied from the perimeter crest, and top surface cells approximately 2 ha in size were developed. At the base of the WRLs, a perimeter sediment retention bund around the toe of the WRLs was installed. Where available, $150 \mathrm{~mm}$ of topsoil was applied, and all surfaces were ripped on the contour. An area specific seed mix (10 kg/ha) and fertiliser ( $50 \mathrm{~kg} / \mathrm{ha})$ was spread by hand. 


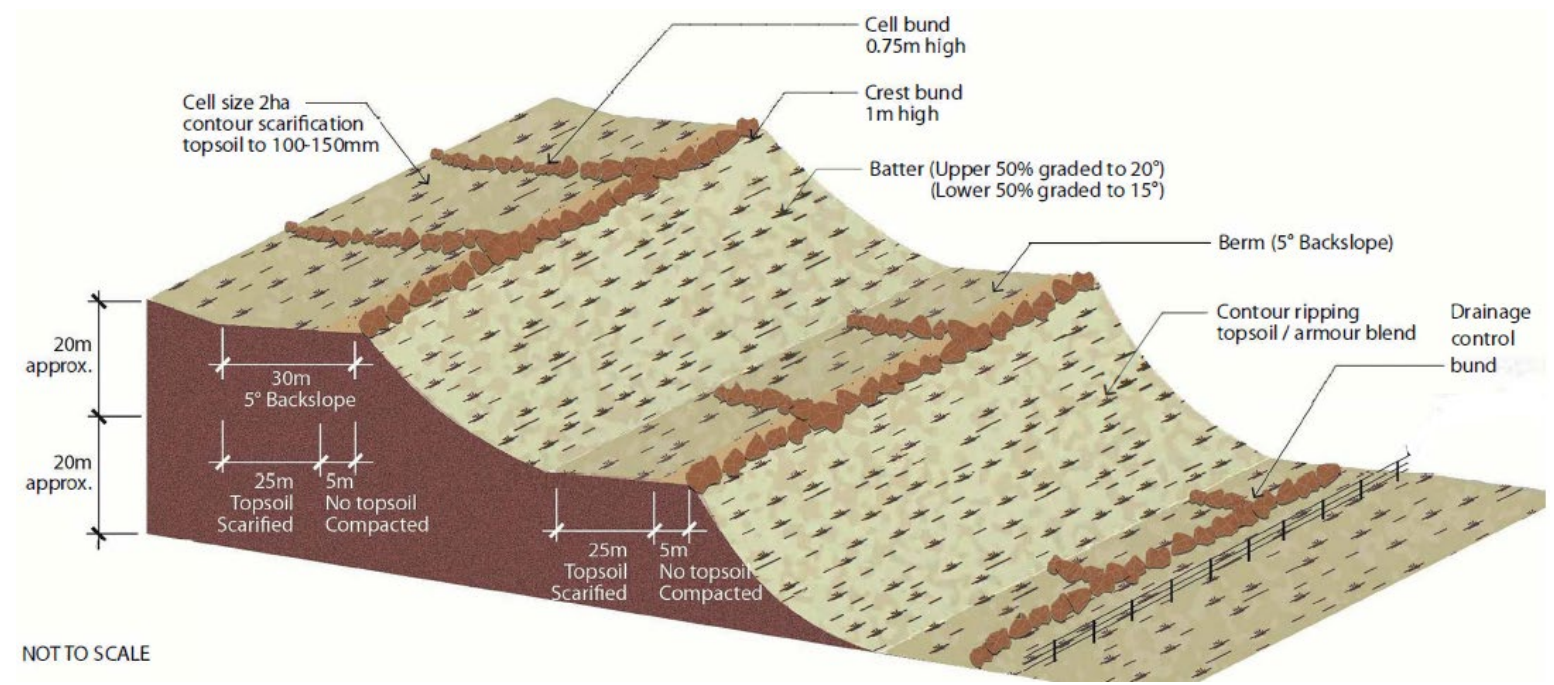

Figure 1 Conceptual closure design for the Project waste rock landforms

\section{$4 \quad$ Closure performance monitoring framework}

Atlas demonstrates closure performance using robust measures including closure objectives and criteria, with the aim to achieve lease relinquishment in a planned and timely manner. Atlas set an ambitious target to achieve lease relinquishment 10 years after the completion of closure works. The closure performance monitoring framework is presented in this section with an emphasis on vegetation and surface water management on the WRLs.

\subsection{Vegetation}

The objective for vegetation is that 'the area will support self-sustaining vegetation which can be reasonably achieved'. The agreed long-term criteria, standards and the monitoring requirements that relate to vegetation are presented in Table 2.

Table 2 Agreed long-term vegetation closure criteria, standards and monitoring requirements (continued next page)

\begin{tabular}{|c|c|c|}
\hline Criteria & Standards & Monitoring requirements \\
\hline $\begin{array}{l}\text { Rehabilitation implemented in } \\
\text { accordance with approved } \\
\text { rehabilitation plan }\end{array}$ & As-built report & $\begin{array}{l}\text { Audit against rehabilitation } \\
\text { plan }\end{array}$ \\
\hline $\begin{array}{l}\text { Vegetation has reached } 70 \% \text { of the } \\
\text { best achievable plant cover at the } \\
\text { Project within specific rehabilitation } \\
\text { zones }\end{array}$ & $\begin{array}{l}\text { Target values are be defined once } \\
\text { plant cover data for rehabilitation } \\
\text { has been collected. To calculate } \\
\text { the standard, the } 70^{\text {th }} \text { percentile } \\
\text { of the average of the top three } \\
\text { performing transects was } \\
\text { determined }\end{array}$ & Vegetation monitoring \\
\hline $\begin{array}{l}\text { Weed cover values are } \leq 10 \% \text { within } \\
\text { four years }\end{array}$ & $\begin{array}{l}\text { Weed cover on rehabilitation is } \\
\leq 10 \% \text { of the total plant cover }\end{array}$ & Vegetation monitoring \\
\hline $\begin{array}{l}\text { Key taxa from nearby floristic } \\
\text { community types (FCTs) occur in the } \\
\text { seed mix for specific domains }\end{array}$ & As-built report & $\begin{array}{l}\text { Audit against rehabilitation } \\
\text { plan }\end{array}$ \\
\hline
\end{tabular}




\begin{tabular}{|c|c|c|}
\hline Criteria & Standards & Monitoring requirements \\
\hline $\begin{array}{l}\text { Vegetation has reached } 70 \% \text { of best } \\
\text { achievable species richness at the } \\
\text { Project within specific rehabilitation } \\
\text { zones }\end{array}$ & $\begin{array}{l}\text { Target values will be defined once } \\
\text { species richness data for } \\
\text { rehabilitation has been collected }\end{array}$ & Vegetation monitoring \\
\hline Vegetation is producing seed & $\begin{array}{l}\text { Monitoring demonstrates that } \\
\text { seed is present on key taxa }\end{array}$ & Vegetation monitoring \\
\hline
\end{tabular}

\subsection{Surface water}

The objective for surface water is that 'uncontrolled surface water flows and impacts to surface water will be minimised'. The criteria, standards and monitoring requirements that relate to surface water are presented in Table 3.

Table 3 Criteria, standards and monitoring requirements for surface water

\begin{tabular}{lll}
\hline Criteria & Standards & Monitoring requirements \\
\hline $\begin{array}{l}\text { Surface water drainage structures } \\
\text { installed as per approved MCP }\end{array}$ & As-built report & NA \\
$\begin{array}{l}\text { Surface water management } \\
\text { structures operating as per design }\end{array}$ & Inspection reports & $\begin{array}{l}\text { Annual closed site inspection } \\
\text { and photo monitoring of key } \\
\text { structures }\end{array}$ \\
Erosion levels on WRLs stabilise & $\begin{array}{l}\text { Erosion monitoring report } \\
\text { Target levels to be developed once } \\
\text { erosion data has been collected on } \\
\text { the WRLs }\end{array}$ & $\begin{array}{l}\text { Assessment of erosion } \\
\text { features }\end{array}$ \\
\hline
\end{tabular}

MCP - mine closure plan; WRL - waste rock landform

\section{$5 \quad$ Performance against criteria}

The closure performance monitoring data, at year five after the completion of closure works, is presented below with an emphasis on the performance of vegetation and surface water management on the WRLs.

\subsection{Vegetation}

As defined in the MCP, closure performance for WRL vegetation was to be demonstrated using as-built reporting and vegetation and weed monitoring results.

\subsubsection{As-built reporting}

As-built reports were required to demonstrate that rehabilitation was implemented in accordance with the approved rehabilitation plan and that key taxa from nearby floristic community types (FCTs) were incorporated into the seed mix for specific domains. The FCTs for the Project were identified during the baseline vegetation and flora identification and mapping assessment.

Prior to undertaking Stage 1 closure works, Atlas developed a Scope of Works (SoW) and associated task sheets for groups of closure tasks for each WRL. The task sheets described the task and associated specifications and were issued to the works supervisor for execution. Each task sheet was completed and signed off by the works supervisor including commentary relating to the works, or variance from the nominated specifications. 
Area specific seed lists were developed based on the FCT's for the Project as defined in the Pardoo rehabilitation plan and were used during rehabilitation activities.

\subsubsection{Vegetation and weed monitoring}

Vegetation monitoring has been undertaken in 2016, 2017 and 2018 on transects established on WRL slopes, top surfaces and associated hardstand areas (Stantec 2018). A total of 30 transects have been monitored which includes seven natural analogue transects in the nearby surrounding environment and 23 WRL transects. Monitoring was undertaken by an external specialist, with transects locations chosen to represent the condition of the WRL.

\subsubsection{Closure criteria}

Using the 2018 WRL vegetation monitoring data, the current closure standards for plant cover, weed cover and species richness have been developed (Table 4) (Stantec 2018). Standards for plant cover and species richness were calculated by firstly averaging the results from the top three performing rehabilitation transects, the $70^{\text {th }}$ percentile of this value was then calculated and used as the standard.

Table 4 Completion criteria standards calculated using data collected at transects during 2018

\begin{tabular}{ll}
\hline Criteria & 2018 standards \\
\hline $\begin{array}{l}\text { Vegetation has reached } 70 \% \text { of the } \\
\text { best achievable plant cover at the }\end{array}$ & $\begin{array}{l}\text { Flats: } 32 \%(70 \% \text { of best achievable data sourced from transects: } \\
\text { PDOject within specific rehabilitation }\end{array}$ \\
$\begin{array}{l}\text { PDOnes } \\
\text { Slopes: } 34 \%(70 \% \text { of best achievable data sourced from } \\
\text { transects: PDO06, PDO09, PDO30) }\end{array}$ \\
$\begin{array}{ll}\text { Weed cover values are } \leq 10 \% \text { within } \\
\text { four years }\end{array}$ & Weed cover $\%$ on rehabilitation is $\leq 10 \%$ \\
$\begin{array}{l}\text { Vegetation has reached } 70 \% \text { of best } \\
\text { achievable* species richness at the }\end{array}$ & $\begin{array}{l}\text { Flats: } 17 \text { plants per } 50 \mathrm{~m} \times 50 \mathrm{~m} \text { quadrat }(70 \% \text { of best achievable } \\
\text { data sourced from transects: PDO10, PDO15, PDO24) }\end{array}$ \\
$\begin{array}{l}\text { zones } \\
\text { Vegethin specific rehabilitation }\end{array}$ & $\begin{array}{l}\text { Slopes: } 16 \text { plants per } 50 \mathrm{~m} \times 50 \mathrm{~m} \text { quadrat }(70 \% \text { of best } \\
\text { achievable data sourced from transects: PDO16, PDO19, PDO30) }\end{array}$ \\
\hline
\end{tabular}

* 'best achievable' $=$ the average of cover values on the three best rehabilitation areas

\subsubsection{Performance against vegetation closure criteria}

A comparison of results for vegetation monitoring against relevant standards for closure criteria (termed 'standards' hereafter) is presented in Table 5. Photographs of rehabilitation on selected WRLs are presented in Figure 2.

During 2018, the standards for perennial plant cover were met at 10 of the 23 transects (Table 5). However, transects not meeting plant cover standards were still showing an increasing trend over time. Those areas which were not performing well, were typically impacted by grazing activities. At the Bobby WRL, poorly performing transects were identified in areas that had to be reworked to improve the accuracy of the initial contour ripping, to avoid future erosion issues. A consequence of reworking these discrete WRL panels was that the topsoil and seed that was initially applied was reworked and buried.

Standards for perennial species richness have been achieved at 14 of the 23 monitoring transects (Table 5) and have been met at most of the transects on the Alice, Chloe, Emma, South Limb and South Limb West WRLs. Although the perennial species richness standard has only been achieved at two of the five transects on the Bobby WRL, an increasing trend in perennial species richness is apparent. 
Table 5 Perennial plant cover, species richness, key taxa seeding and weed cover from the 2018 WRL monitoring data in comparison to standards (Table 4). Green = standard has been met; Red $=$ standard is yet to be achieved

\begin{tabular}{|c|c|c|c|c|c|}
\hline Landform & Transect & $\begin{array}{l}\text { Native plant } \\
\text { cover (\%) }\end{array}$ & $\begin{array}{l}\text { Native species } \\
\text { richness (no. } \\
\text { species per } \\
\text { transect) }\end{array}$ & $\begin{array}{c}\text { Key taxa } \\
\text { seeding }\end{array}$ & $\begin{array}{c}\text { Weed cover } \\
\text { (\%) }\end{array}$ \\
\hline \multirow[t]{2}{*}{ Alice WRL slope } & PDO02 & 14 & 19 & Yes & 7.1 \\
\hline & PDO12 & 11 & 6 & Yes & 8.2 \\
\hline Alice WRL top flat & PDO01 & 29 & 22 & Yes & 0.7 \\
\hline \multirow[t]{3}{*}{ Bobby WRL slope } & PDO06 & 46 & 19 & Yes & 0.1 \\
\hline & PDO07 & 0.2 & 11 & No & 20 \\
\hline & PDO08 & 11 & 13 & Yes & 5.3 \\
\hline \multirow[t]{2}{*}{ Bobby WRL top } & PDO04 & 21 & 19 & Yes & 1.0 \\
\hline & PDO05 & 0 & 9 & No & 2.9 \\
\hline \multirow[t]{2}{*}{ Chloe WRL slope } & PDO09 & 52 & 20 & Yes & 0.2 \\
\hline & PDO30 & 49 & 26 & Yes & 0.2 \\
\hline Chloe WRL top flat & PDO10 & 38 & 25 & Yes & 0.0 \\
\hline Chloe hardstand & PDO11 & 43 & 15 & Yes & 0.0 \\
\hline \multirow[t]{3}{*}{ Emma WRL slope } & PDO14 & 46 & 13 & Yes & 0.1 \\
\hline & PDO16 & 6 & 20 & Yes & 0.1 \\
\hline & PDO19 & 24 & 24 & Yes & 0.2 \\
\hline \multirow[t]{2}{*}{ Emma WRL top flat } & PDO13 & 9.8 & 17 & Yes & 0.6 \\
\hline & PDO15 & 27 & 25 & Yes & 0.6 \\
\hline Emma hardstand & PD017 & 12 & 10 & No & 0.1 \\
\hline Emma borrow pit & PDO20 & 6.0 & 20 & Yes & 0.0 \\
\hline \multirow{2}{*}{$\begin{array}{l}\text { South Limb WRL } \\
\text { slope }\end{array}$} & PDO23 & 14 & 17 & Yes & 0.0 \\
\hline & PDO25 & 45 & 19 & Yes & 0.1 \\
\hline $\begin{array}{l}\text { South Limb West } \\
\text { WRL slope }\end{array}$ & PDO26 & 12 & 23 & Yes & 1.1 \\
\hline $\begin{array}{l}\text { South Limb WRL } \\
\text { top flat }\end{array}$ & PDO24 & 56 & 14 & Yes & 0.0 \\
\hline
\end{tabular}



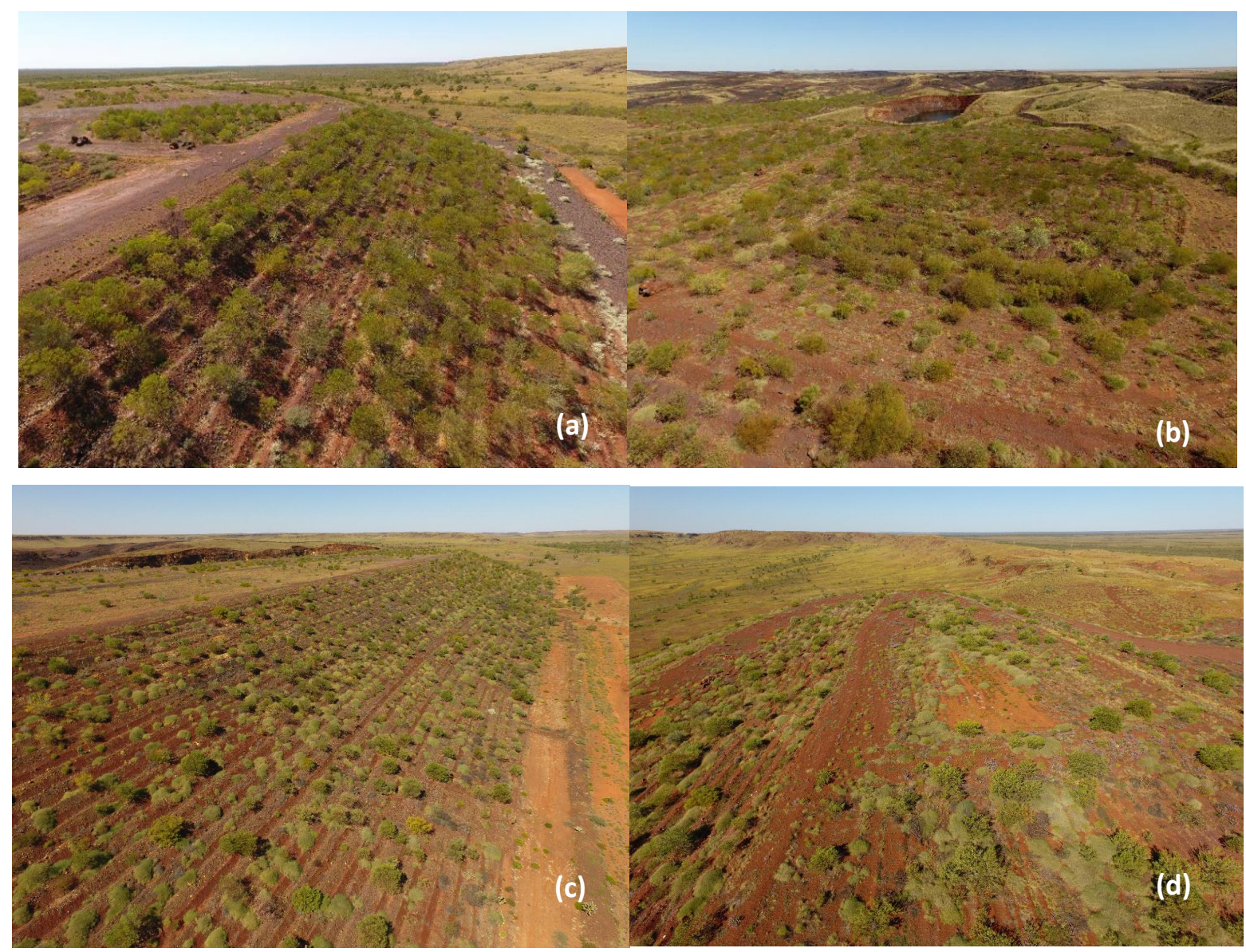

Figure 2 Plant growth on the (a) Bobby, (b) Chloe, (c) Emma and (d) South Limb WRLs

The criterion that key taxa (Acacia and Triodia) are producing seed, has been achieved at all transects except for two on the Bobby WRL (slope transect PDO07 and top surface transect PDO05) and one on the Emma hardstand area (PDO17). These transects reported little to no plant cover and it is likely that they were devoid of the key taxa, most likely as a result of grazing (Table 5).

The weed cover standard was met at all transects, except for one transect on the Bobby WRL (Table 5). This transect was located on one of the reworked panels of the WRL where little vegetation had established.

Transects where all vegetation standards (plant cover, species richness, weed cover and key taxa producing seed) have been met include the Alice WRL top surface (PD01), Bobby WRL slope (PD06), Chloe WRL slopes and top surface (PD09, PD10 and PD30), Emma WRL top surface (PD015) and South Limb WRL slope (PD025) (Table 5). 


\subsection{Surface water}

As defined in the MCP, closure performance for WRL surface water management related works was to be demonstrated using as-built reporting, inspection reports (including photo-point monitoring) and erosion monitoring results, as described in Table 6.

Table 6 Proportion of slope eroded (\%) of rehabilitation transects

\begin{tabular}{lcccc}
\hline Landform & Transect & \multicolumn{3}{c}{ Proportion of slope eroded (\%) } \\
& no. & 2016 & $\mathbf{2 0 1 7}$ & $\mathbf{2 0 1 8}$ \\
\hline Alice WRL top flat & PDO01 & 0.0 & 0.0 & 0.0 \\
Alice WRL slope & PDO02 & 2.1 & 1.0 & 0.0 \\
Bobby WRL top flat & PDO04 & 0.0 & 0.0 & 0.0 \\
Bobby WRL top flat & PDO05 & 0.0 & 0.0 & 0.0 \\
Bobby WRL slope & PDO06 & 2.5 & 1.8 & 3.4 \\
Bobby WRL slope & PDO07 & 0.7 & 0.0 & 0.0 \\
Bobby WRL slope & PDO08 & 2.6 & 3.6 & 4.2 \\
Chloe WRL slope & PDO09 & 2.3 & 0.8 & 0.8 \\
Chloe WRL top flat & PDO10 & 0.0 & 0.0 & 0.0 \\
Chloe Hardstand flat & PDO11 & 0.0 & 0.0 & 0.0 \\
Alice WRL slope & PDO12 & 0.0 & 0.0 & 0.0 \\
Emma WRL top flat & PDO13 & 0.0 & 0.0 & 0.0 \\
Emma WRL slope & PDO14 & 1.8 & 4.9 & 5.1 \\
Emma WRL top flat & PDO15 & 0.0 & 0.0 & 0.0 \\
Emma WRL slope & PDO16 & 0.0 & 0.0 & 0.0 \\
Emma hardstand flat & PDO17 & 0.0 & 0.0 & 0.0 \\
Pardoo analogue flat & PDO18 & 0.0 & 0.0 & 0.0 \\
Emma WRL slope & PDO19 & 0.0 & 1.2 & 1.2 \\
Emma hardstand flat & PDO20 & 0.0 & 0.0 & 0.0 \\
South Limb WRL slope & PDO23 & 0.0 & 0.0 & 0.0 \\
South Limb WRL top flat & PDO24 & 0.0 & 0.0 & 0.0 \\
South Limb WRL slope & PDO25 & 0.0 & 0.0 & 0.0 \\
South Limb West WRL slope & PDO26 & 0.0 & 0.0 & 0.0 \\
Chloe WRL slope & PDO30 & 0.0 & 0.0 & 0.0 \\
\hline WR-wstroc & & & & \\
\hline
\end{tabular}




\subsubsection{As-built reporting}

As-built reports were required to demonstrate that surface water drainage controls were installed as per the approved MCP. As described in Section 5.1, SoW documentation and associated task sheets were developed for groups of closure tasks for each WRL. Task sheets were completed and signed off by the works supervisor including commentary relating to the works, or variance from the nominated specifications.

\subsubsection{Visual inspections}

Visual inspections and photo-point monitoring of key WRL surface water controls (armoured drains, crest bunds, contour ripping) are undertaken on a yearly basis. Results from all inspections have determined that WRL surface water controls are functioning effectively and in accordance with their designs. Some minor erosion on WRL slopes has been reported as discussed in the following sections.

The UAV survey undertaken during November 2018 captured orthophoto data from each WRL. DEM data and elevation heatmaps were generated and analysed to determine if WRL surface water control features, including top surface catchment cells, crest bunds, berms and perimeter flood and drainage controls, were functioning as-designed (Figure 3).

The assessment identified that the top surfaces of the South Limb, South Limb West, Bobby, Chloe and Alice WRLs are relatively flat, with crest and internal bunds sufficiently elevated above the top surface level, to prevent overtopping onto the batters. No low-lying areas adjacent to the crest bunds were identified as high-risk areas for potential future erosion. 


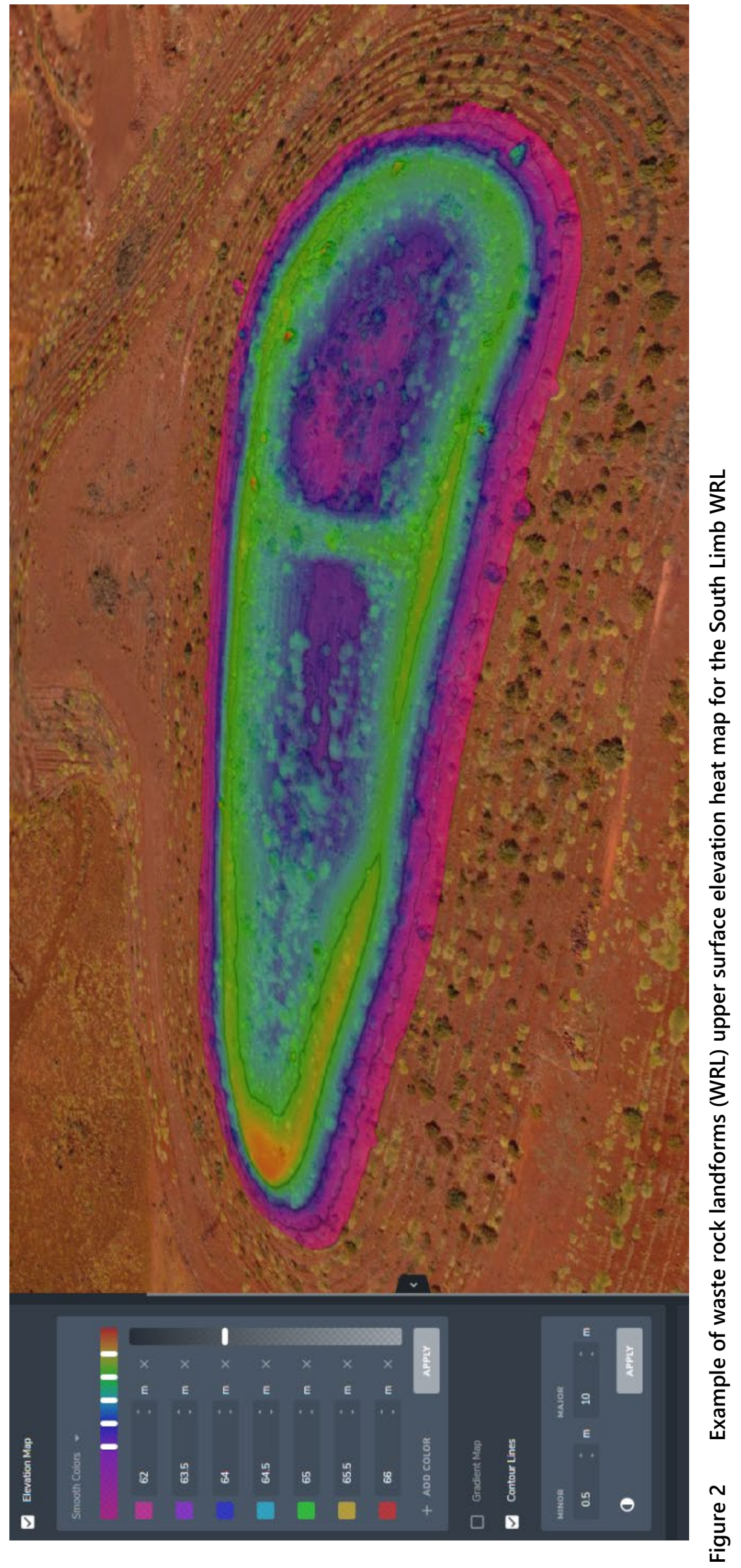




\subsubsection{Erosion monitoring}

Erosion monitoring on the rehabilitated WRLs has been conducted on three occasions since 2016 using traditional transect methods, to derive the proportion of the bank which has been eroded along a representative transect (Table 6). The criterion to measure closure performance is that 'erosion levels on the WRLs stabilise.'

Monitoring since 2016 has only identified erosion features at seven of the 23 monitoring transects (Stantec, 2018). The average rate of change for erosion between 2016 and 2018 at these six transects was calculated to be $0.4 \%$. This value will constitute the interim standard for coming years and will be updated as additional erosion data becomes available.

During 2018, a whole of landform assessment of erosion was undertaken on the South Limb, South Limb West, Bobby, Chloe and Alice WRLs (Mine Earth, 2019). The assessment utilised orthophoto and DEM data collected from a UAV survey undertaken in November 2018 to identify and quantify, where possible, the volumes and spatial attributes of erosion features on the WRLs. Since rehabilitation has been completed several large rainfall events have occurred, particularly in January 2014 and January 2016. The largest event represented a 1-in-10 year average recurrence interval event.

Each gully identified from the orthophotos and DEM was classified according to its severity, based on several features such as gully length, gully volume, sediment movement and the catchment size contributing to the gully. Most erosion features identified on the WRLs were relatively minor and were classified as 'Green: Minor gully, no immediate threat to erosion stability and/or surface drainage control, to be monitored over time'. Eleven gullies were classified as 'Amber: Substantial gully to be closely monitored over time, potential threat to erosion stability and/or surface drainage control'. None of the gullies were classified as 'Red: Severe gully, current threat to landform erosion stability and/or surface drainage control, remediation required'. This method identified far more erosion features than the traditional erosion transect method.

Most of the 'Amber' gullies at the Project were classified due to factors such as gully length, rather than high volume or sediment movement beyond the toe of the landform. Three 'Amber' gullies were identified on South Limb WRL (Figure 4), three on South Limb West WRL and five on the Bobby WRL. There were no amber gullies identified on the Chloe or Alice WRLs.

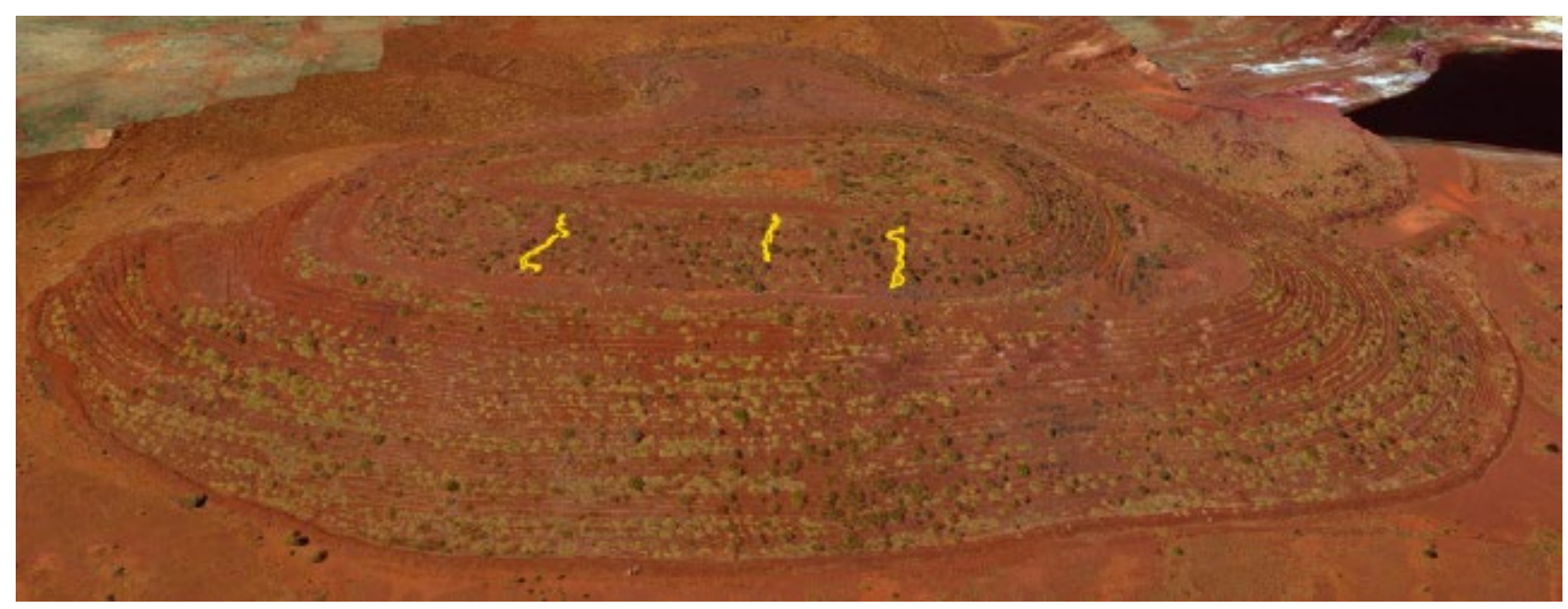

Figure 4 Identified erosion gullies on the South Limb WRL

Annual UAV surveys and associated landform scale erosion assessments will be undertaken to revisit each of the gullies identified from the 2018 'baseline' assessment. The results from landform scale assessments of erosion will generate a robust erosion rate of change value, which will be applied as a standard for the erosion closure criteria. 


\section{Conclusion}

Early rehabilitation success at the Project has been the result of a comprehensive planning and implementation process. Risk assessment, identification of knowledge gaps and associated studies and stakeholder engagement contributed to the development of a robust MCP.

The outputs of the MCP were implemented at the Project during the closure works and monitoring of surface water and vegetation attributes on the WRLs are showing positive trends. Advances in monitoring techniques such as the collection of landform scale data to support erosion assessments have also been developed and will be used over time to demonstrate the achievement of closure criteria.

\section{Acknowledgement}

The authors thank Atlas Iron Pty Ltd for providing the data for this paper.

\section{References}

Atlas 2013, Pardoo Mine Closure Plan, October 2013, prepared by Mine Earth.

International Organization for Standardization 2009, Risk Management - Principles and Guidelines (ISO31000:20090), Geneva.

Mine Earth 2012, Closure Recommendations for Waste Rock Landforms, November 2012, internal report for Atlas Iron Pty Ltd.

Mine Earth 2019, Pardoo DSO Project, Mine Waste Landform Erosion Assessment, February 2019, internal report for Atlas Iron Limited.

MWH 2013, Pardoo Mine Closure Hydrological Investigation, January 2013, prepared for Atlas Iron Limited.

Outback Ecology Services (OES) 2012, Pardoo DSO Project, Soil Resource Assessment, November 2012, internal report for Atlas Iron Pty Ltd by Outback Ecology Services.

Stantec 2018, Rehabilitation Assessment of the Pardoo Mine, November 2018, prepared for Atlas Iron Limited.

Trajectory 2013, Pardoo Mine Rehabilitation Plan, January 2013, internal report for Atlas Iron Pty Ltd. 
